(1)

GeORgE Fox

UNIVERSITY
Digital Commons @ George Fox University

$7-2020$

Examining the Relationships Between Innovation, Quality, Productivity and Customer Satisfaction in Pure Service Companies

Dongjun Rew

Joo Jung

Steve Lovett

Follow this and additional works at: https://digitalcommons.georgefox.edu/gfsb

Part of the Business Administration, Management, and Operations Commons, and the Strategic Management Policy Commons 


\title{
Examining the relationships between innovation, quality, productivity, and customer satisfaction in pure service companies
}

\begin{abstract}
Purpose - This study investigates the relationships between innovation, quality, productivity, and customer satisfaction in pure service companies. Previous studies have shown a negative relationship between quality and productivity in services. However, we argue the two can be positively related when innovation is present.

Design/methodology/approach - We develop and test our hypotheses using the secondary data from the COMPUSTAT, KLD STAT, and the American Customer Satisfaction Index (ACSI). We test our hypotheses using ordinary least squares regression and conduct additional testing using path analysis.
\end{abstract}

Findings - The findings show that quality and productivity are positively related when innovation is present in pure service companies. We also find that innovation is antecedent to both service quality and productivity which in turn positively affect customer satisfaction.

Practical Implications - Both companies and customers can increase their outcomes including higher levels of service quality, productivity and customer satisfaction. Managers should therefore design innovative systems that enable customers to participate in service production. Other innovative systems may help to increase capacity utilization by smoothing high and low demand times, thus increasing both service quality and productivity.

Originality/value - This study contributes to service research by identifying innovation as the key to simultaneously increasing service quality and productivity. We find empirical support for a model in which service quality and productivity have a complementary relationship leading to customer satisfaction with innovation as an antecedent, and we do so using a sample of pure service firms.

Keywords: quality, productivity, innovation, customer satisfaction, service

Paper type: Research paper 


\section{Introduction}

The portion of services in the US economy has been increasing for some time (Worstall, 2016). According to the World Bank (2018), 79\% of the value of the US market and 69\% of the world market is from the services sector, and these figures will continue to grow for the foreseeable future. Two key aspects enhance a company's value in the services market: quality and productivity (Grönroos and Ojasalo, 2004). In fact, Calabrese (2012) referred to these as the two main performance drivers for service companies. Perceived quality leads to positive customer behaviors such as repurchasing of the service (Anderson and Sullivan, 1993; Fornell et al., 2016; Zeithaml et al. 1996). But companies must also consider service productivity in order to be profitable (Yen et al., 2012). Therefore, it is important for service researchers to understand the relationship between service quality and productivity.

However, the literature has taken conflicting views on this relationship. Over two decades ago both Huff et al. (1996) and Anderson et al. (1997) argued that there was generally a negative relationship between service productivity and perceived service quality or customer satisfaction. This is because quality may be improved by increasing the number of employees while productivity may be increased by reducing labor costs. Furthermore, this tradeoff should be more prevalent in services than in manufacturing because in services perceived quality is more dependent on customization, which is labor intensive, while in manufacturing perceived quality is dependent on standardization and freedom from defects, which is not labor intensive. On the other hand, Grönroos and Ojasalo (2004) and Calabrese (2012) claimed that service businesses may in some circumstances improve both quality and productivity. 
We believe that innovation is the key to simultaneously improving service quality and productivity. Innovative services may result from the use of advanced technology, but even more importantly from an innovative mindset throughout the company. This innovative mindset is necessary because our current service-based economy is not only a traditional exchange system emphasizing sellers, buyers and efficiency, but also an innovative exchange system emphasizing co-creation and experiences (Vargo and Lusch, 2004, 2008a, 2008b; Vargo et al., 2008).

Therefore, it is necessary to find an innovative approach to creating and maintaining customer satisfaction through reshaping and understanding the relationship between service quality and productivity.

In this study we focus on the pure service companies. Anderson et al. (1997) opined that the quality/productivity tradeoff should be most prevalent in the "purer" services, and used airlines, banks, charter travel and shipping as examples. Other examples of pure services companies include medical services such as hospitals and pharmacies, financial services such as insurance companies and banks, leisure services such as hotels, and legal services such as law firms. On the other hand, retailers and fast food restaurants deliver a goods-services package to their customers, and so are not pure services companies. We look for answers to the following research questions:

1. What is the relationship between innovation, quality, productivity and customer satisfaction in pure service companies?

2. What is the role of innovation in this relationship in pure service companies?

The first of these questions is rather controversial in existing literature, mainly in the service quality and productivity relationship. Some authors suggest a complementary relationship between two (Yee et al., 2008, Parasuraman, A., 2010, Choi et al., 2015), while others suggest a 
contradictory relationship (Anderson et al. 1997; Huff et al., 1996; Rust and Huang, 2012). Still, the primary contribution of this study results from the second research question. We propose service innovation as an antecedent to both service quality and productivity, allowing companies to increase both simultaneously and ultimately increase customer satisfaction.

The next sections of this study will present a literature review, a theoretical research framework based on that review, our methodology, a discussion including managerial implications, and conclusions.

\section{Literature review and research hypotheses}

Service-Dominant (S-D) logic is a meta-hypothetical framework to explain value creation through exchange in the economic setting where service is the fundamental basis of exchange (Vargo and Lusch, 2004, 2008a, 2008b; Vargo et al., 2008). S-D logic emphasizes customers and their roles, and the concept of customer satisfaction has been an important research topic in various business disciplines, but especially in management and marketing (Churchill and Surprenant, 1982; Fornell et al., 2016). Dissatisfied customers are more likely to defect to competitors (Fornell and Wernerfelt, 1987, 1988; Hirschman, 1970; Kasiri et al., 2017), and satisfied customers are more likely to repurchase (Anderson and Sullivan, 1993; Fornell et al., 2016; Zeithaml et al. 1996), so customer satisfaction is an important determinant of firms' financial performance. Therefore, it is important for business researchers to understand why customer satisfaction is important and to investigate how to satisfy customers and maintain their satisfaction. 
Oliver (1980) described customer satisfaction as the result of expectation and disconfirmation effects. A high level of satisfaction comes from reducing the gap between customers' expectation of a service and the confirmation of the expectation. Companies diminish the gap by discovering customers' expectations and by providing a fitting service. Consumers are both rational and emotional when they attempt to make a decision (Holbrook and Hirschman, 1982), and form their attitudes toward any object, including a service, based on their experience with the quality or function of the object. Attitudes lead to expectations (Parasuraman et al., 1985), and customers are likely to refuse any product or service when their experience disconfirms their expectations. In other words, customer satisfaction is established by meeting customers' expetations of quality. Much of existing literature has supported this point of view (Hallowell, 1996; Hennig-Thruau and Klee, 1997; Kasiri et al., 2017; Rahmi and Kozak, 2017; Szymanski and Henard, 2001).

But in addition to meeting customers' expectations of quality, service providers must also be productive. Grönroos and Ojasalo (2004) provide a model relating service productivity, quality and customer satisfaction, and show how the relationship between productivity and quality is different in manufacturing versus service situations. In the Grönroos and Ojasalo (2004) model service productivity is simultaneously a function of internal or cost efficiency, external efficiency or perceived quality, and capacity efficiency. Internal efficiency can be conceptualized as a ratio of outputs produced over inputs used, as in manufacturing situations.

But in manufacturing quality is assumed to remain constant as productivity improves. For example, the wooden tables produced on an automated assembly line might be identical to those produced one by one by individual workers. But the constant quality assumption rarely applies in services production. If an insurance company replaces its customer service representatives with 
an automated call center and customers do not like the call center, perceived quality has declined, and if many customers defect the gains in internal efficiency are offset. Furthermore, service productivity is influenced by demand. If the insurance company’s customer service representatives sit idle for most of the day but then are overwhelmed at peak hours, both internal efficiency and perceived quality decline, and the insurance company cannot build up inventory to use as a buffer to mitigate this problem as can the table manufacturer. In service businesses, therefore, internal or cost efficiency, external efficiency or perceived quality, and capacity efficiency must be considered simultaneously to determine productivity. In the remainder of this section, we will use the Grönroos and Ojasalo (2004) model to develop hypotheses relating innovation, quality, productivity and customer satisfaction in pure service companies.

\section{Customer satisfaction and service quality}

In the Grönroos and Ojasalo (2004) model customer satisfaction results from service quality, and the same is true in most services research. Taylor and Baker (1994), for example, supported this point of view, as did Fornell et al. (1996), who showed that quality in the services sector can be measured by the perception of customers who have already experienced the service. More recently, Cheruiyot and Maru (2013) argued that service quality positively influences relative performance in the field of education. But quality ultimately comes from employees, and employees with high job satisfaction actively engage in the process of producing services and caring for customers. These behaviors increase the likelihood that customers will have positive reactions (Yee et al., 2008). We propose the following hypothesis:

H1. Service quality positively affects customer satisfaction. 


\section{Customer satisfaction and service productivity}

Service providers holding the traditional or manufacturing perspective may attempt to increase their productivity by reducing their inputs and especially their labor force, thereby reducing customer satisfaction (Anderson and Sullivan, 1993; Anderson et al., 1997). However, service production requires not only inputs from the service provider but also inputs from the customer (Grönroos and Ojasalo, 2004). Companies in the service-oriented market may therefore design their service processes to facilitate customer participation which may also increase the level of customer satisfaction. Thus, customer participation in the process of producing a product/service can increase the level of productivity as well as customer satisfaction. Furthermore, in at least some cases customer participation can increase employee satisfaction and performance (Yi et al., 2011), which may result in even greater service productivity and customer satisfaction. Based on this argument, we propose the following hypothesis:

H2. Service productivity positively affects customer satisfaction.

The problematic relationship between service quality and productivity

The traditional output over input measure leads to the conclusion that companies can increase their productivity by reducing labor, which implies a negative relationship between productivity and quality in service industries because quality is strongly influenced by the interaction between customers and employees (Gummesson, 2008). However, we believe that a positive relationship between productivity and quality should exist within pure service companies for two reasons. First, as previously mentioned, both productivity and quality are improved by the customers' participation in the production process. Second, as previously mentioned, capacity utilization is key to both productivity and quality in the service production process (Grönroos and Ojasalo, 
2004). The most effective service providers will be those that can manage their capacity well, and doing so will benefit both service quality and productivity. Thus, we propose the following hypothesis.

H3. Service quality is positively associated with service productivity.

The role of innovation in the formation of customer satisfaction

Several authors (Berry et al., 2006; Coombs and Miles, 2000; Witell et al., 2016) have emphasized the importance of innovation in the service production process, and in fact innovations abound in pure service industries. Some service innovations are radical, or Schumpeterian (Schumpeter, 1934). These are require new knowledge, and occur rarely. An example is the introduction of ATM machines in the banking industry. Berry et al., (2006) emphasized this kind of innovation, noting that new technology can improves firm profitability by increasing both service quality and productivity. But many more opportunities are incremental, or Kirznerian (Kirzner, 1973). These require only the effective application of existing knowledge. An example might be a new training program to help bank tellers to recognize when customers might benefit from existing banking services and suggest these services to them. Cheng et al. (2012) emphasized that this kind of customer involvement in the process of service innovation may be positively associated with customer satisfaction because it increases the possibility of providing high-value services. Either kind of innovation can affect customer satisfaction in a variety of ways. An entirely new service can positively affect customer perceived quality, while more incremental innovations can enhance the customer's inputs into existing services. 
Still, service innovation comes primarily from an innovative mindset throughout the company (Agarwal et al., 2003; Cheng and Krumwiede, 2012; Hurley and Hult, 1998).

Innovative activities in a service company include designing systems that systematically involve customers in the process of producing a service and quickly discovering customers' evaluations of the service (Hollebeek and Andreassen, 2018). Through such systems, both service quality and productivity may be increased. This type of innovation magnifies the effect of service productivity on the level of customer satisfaction. Badescu and Garces-Ayerbe (2009) showed that investment in such a system impacts firm productivity because it contributes to labor productivity. Mansury and Love (2008) showed that external innovation, including customer participation, had a positive impact on service firm performance because of the interaction between customers and the company. Thus, companies’ efforts to develop innovative processes to develop services with customer participation are beneficial for both the companies and the customers. We propose the following hypotheses:

H4. Service innovation positively affects service quality to increase customer satisfaction.

H5. Service innovation positively affects service productivity to increase customer satisfaction.

We therefore propose the following research framework which shows the relationships among (a) innovation and service quality and productivity, (b) service quality and productivity and customer satisfaction, and (c) service quality and productivity. The research framework and hypotheses are shown in the Figure 1. 
Figure 1. Hypothetical relationships among innovation, quality, productivity, and customer satisfaction in the pure services sector

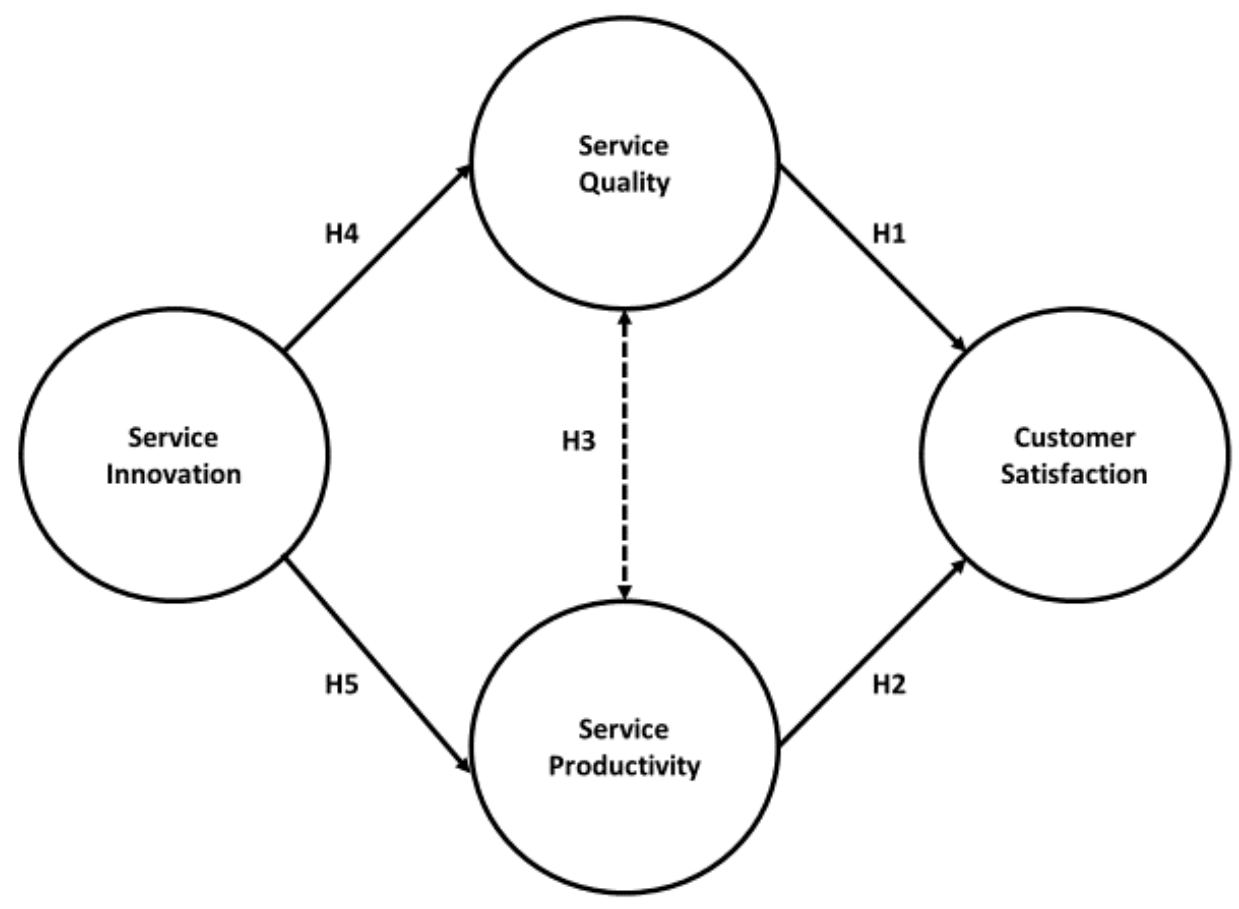

\section{Method}

Data

We used data from COMPUSTAT, KLD STAT, and the American Customer Satisfaction Index (ACSI). Each set of data has different attributes. COMPUSTAT provides accounting information about public companies in US and Canada. KLD data provides information about US companies’ business activities including employee empowerment, employee job satisfaction, and companies’ environmental contribution to quantify their social and environmental performance. The ACSI measures customer satisfaction.

Service firms were identified using COMPUSTAT’s Standard Industrial Classification (SIC) system code (4000-8900). As mentioned previously, we focused on pure service 
companies, or those that do not deliver a goods-services package to their customers. We matched COMPUSTAT and KLD data using the Committee on Uniform Security Identification Procedures (CUSIP) code. We then matched the ACSI scores with the matched set of COMPUSTAT and KLD STAT scores. The final sample contained 48 observations of service companies over the three-year period from 2012 to 2014.

\section{Measurement}

To measure service quality (SQ) we used KLD STAT, which quantifies the social and environmental performance of each company. Specifically, we used employee engagement and employee satisfaction to measure service quality. Service quality ultimately comes from employee participation in the process of service production. Satisfied employees are more likely to work hard and provide better service (Calabrese, 2012; Yoon and Suh, 2003), and are more involved in their organizations (Adeinat and Kassim, 2019; Yee et al., 2008).

We used the ACSI dataset to measure customer satisfaction (CS). This dataset is intended to be representative of the national economy, and includes all major sectors including services. Two hundred and fifty randomly selected customers who have already purchased the product and/or service of each company within a sector were interviewed by phone to evaluate the experience (Fornell et al., 1996). The ACSI dataset includes more than 400 public companies.

To measure service innovation (SI), we used research and development expenditures divided by total assets (Hurley and Hult, 1998; Kibbeling et al., 2013; Padgett and Galan, 2010; Peterson and Jeong, 2010), taken from COMPUSTAT. To measure service productivity (SP), we used sales divided by the number of employees, taken again from COMPUSTAT. There has been a vigorous discussion about measuring service productivity in this way (Anderson et al., 
1997; Grönroos and Ojasalo, 2004; Rust and Huang, 2012), but in the pure services sector labor plays an especially important role.

\section{Results}

Descriptive statistics and correlations

Table 1 presents descriptive statistics and correlations for all variables. Table 2 presents the relationship between service innovation and the dependent variables: service quality (SQ), service productivity (SP), and customer satisfaction (CS). We used Ordinary Least Squares (OLS) regression to test hypotheses 1, 2, 4, and 5 (Table 2), and a correlation to test hypothesis 3 (Table 1).

Table 1. Descriptive statistics and correlations

\begin{tabular}{l|r|r|r|r|r|r}
\hline & \multicolumn{1}{|c|}{ Mean } & \multicolumn{1}{c|}{ St. Dev. } & \multicolumn{1}{c|}{$(1)$} & \multicolumn{1}{c|}{ (2) } & (3) & (4) \\
\hline SI (1) & 0.017 & 0.026 & 1.000 & & & \\
\hline SP (2) & 5.075 & 0.934 & $0.443^{*}$ & 1.000 & & \\
\hline SQ (3) & 3.710 & 1.637 & $0.372^{*}$ & $0.626^{*}$ & 1.000 & \\
\hline CS (4) & 80.540 & 3.421 & -0.194 & $0.351^{*}$ & $0.508^{*}$ & 1.000 \\
\hline
\end{tabular}

Notes: *Sig. at $p<0.05, \mathrm{SI}=$ service innovation (Var. 1 ), $\mathrm{SP}=$ service productivity (Var. 2 ), $\mathrm{SQ}=$ service quality (Var. 3), CS = customer satisfaction (Var. 4), St. Dev. = standard deviation 


\section{Hypothesis testing}

We found that service quality and productivity were both positively associated with customer satisfaction $(t=3.996, p=.000$ and $t=2.540, p=.001)$. These findings support hypotheses 1 and 2. We also found a positive correlation between productivity and quality in service $(r=.626$, $p<.05$ ), supporting hypothesis 3 . We found that service innovation had positive relationships with service quality $(t=2.722, p=.009)$ and productivity $(t=3.351, p=.002)$. Furthermore, both service quality and productivity were positively correlated with customer satisfaction ( $r$ $=.508, p<.05$ and $r=.351, p<.05)$. Hypotheses 4 and 5 were supported.

Table 2. Results of regression analysis

\begin{tabular}{l|r|r|r|r}
\hline Model & \multicolumn{1}{|c|}{ Coef. } & \multicolumn{1}{c|}{ Std. Err } & \multicolumn{1}{c|}{$\boldsymbol{t}$-value } & \multicolumn{1}{c}{$\boldsymbol{p}$-value } \\
\hline SQ $\rightarrow$ CS & 1.061 & 0.265 & 3.996 & 0.000 \\
\hline SP $\rightarrow$ CS & 1.283 & 0.505 & 2.540 & 0.001 \\
\hline SI $\rightarrow$ SQ & 23.091 & 8.483 & 2.722 & 0.009 \\
\hline SI $\rightarrow$ SP & 15.685 & 4.681 & 3.351 & 0.002 \\
\hline
\end{tabular}

Notes: Coef. $=$ coefficient, Std. Err $=$ Standard Error

\section{Additional testing}

To look for key driver constructs, we also conducted structural equation modeling (SEM). There are two different types of SEM: covariance-based SEM (CB-SEM) and partial least squares SEM (PLS-SEM). We employed PLS-SEM because it has features that are less sensitive to the size of sample and it is designed to identify key driver constructs (Hair et al., 2014). 
According to previous studies on assessing goodness of fit or model-fit (Bentler and Bonett, 1980; Lohmoller, 1989; Hair et al., 2014), the theoretical research frame was well supported by various statistical indicators that evaluate fit. For example, threshold values for the standardized root mean square residual are usually set at less than .1 or .08 , while we found a value of .013. Also, threshold values for the normed fit index are usually set at greater than .900 , while we found a value of .970. We therefore looked for theoretical relationships among the variables and verified their statistical significance through path analysis. Path analysis allows us to investigate the directed dependencies among a set of variables through a structural model (Hair et al., 2014). The result is presented in Figure 2 below.

Figure 2. The results of testing the directed dependencies among variables

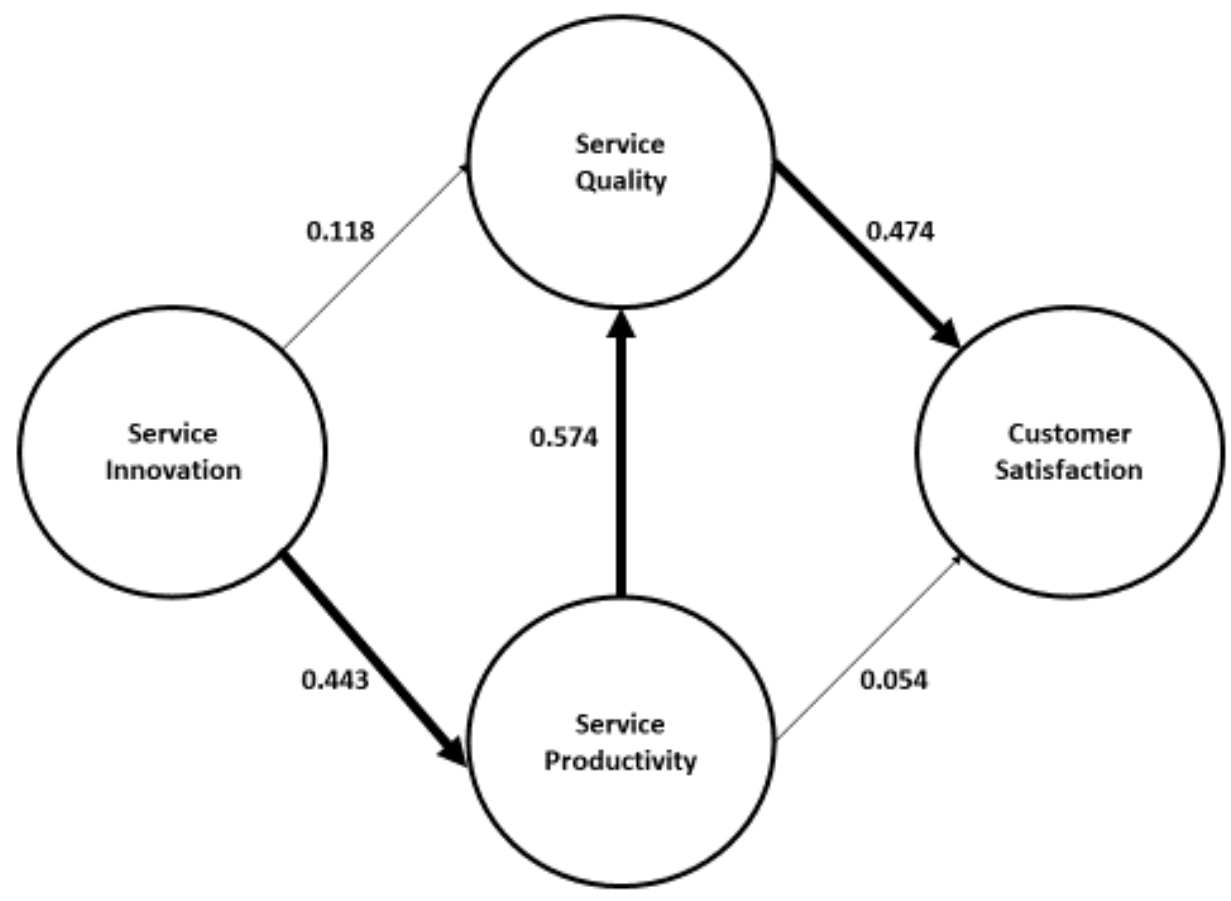

Figure 2 supports our theoretical arguments that innovation in service positively affects both service productivity and quality, and that productivity and quality play an important role in constructing customer satisfaction. More importantly, innovation plays an important role as an 
antecedent of service quality and productivity by positively influencing both. Moreover, the results show there is a theoretical or sequential order of the dependencies among innovation, service productivity and quality; that service innovation positively affects productivity, productivity increases service quality, and then quality leads to customer satisfaction.

\section{Discussion}

\section{Theoretical implications}

What is the relationship between service quality and productivity? This question has been addressed in research since the late 1990s (Anderson et al., 1997; Calabrese, 2012; Grönroos and Ojasalo, 2004; Huff et al., 1996; Rust and Huang, 2012) with inconclusive empirical findings. However, this study contributes to service research by finding a positive association or complementary relationship between service quality and productivity within pure services companies.

The key to this complementary relationship is service innovation. Service innovation can encourage customers to actively engage in the process of producing services (Hollebeek and Andreassen, 2018). Service productivity can often be increased by the participation of customers in the process of producing services (Anderson et al., 1997; Lee et al., 2017; Lovelock and Young, 1979; Parasuraman et al., 1985; 1988; 1994), and this participation can also increase service quality because customers can specify what they want from the service (Grenci and Watts, 2007). Furthermore, service innovations can also increase capacity utilization (Grönroos and Ojasalo, 2004), and so increase both productivity and quality. Thus, innovation in services production can lead to increases in both service quality and productivity. 
At first glance our findings may seem to be in conflict with those of previous authors, but a more careful inspection reveals that this is not the case. For example, Huff et al. (1996) proposed that for most services the quality-productivity relationship will be negative, but cautioned that they were assuming stable technology, and predicted that advances in technology might make it possible to improve both simultaneously. Likewise, Anderson et al. (1997) argued that there was in general a tradeoff between productivity and perceived quality or customer satisfaction in services, but still allowed for the possibility of increasing both simultaneously and cited applications of information technology as a likely example. Of course, this is very similar to our more general suggestion that productivity and quality can both be improved given innovation. In fact, Anderson et al. (1997) suggested that accounting for the impact of technology on the relationship between productivity and perceived quality would be an interesting avenue for future research, and therefore in a sense predicted our study. Rust and Huang (2012) provide a more recent comparison. These authors postulated a trade-off between service quality and productivity, but were careful to note that this trade-off applied at a given level of technology, and that with advanced technology a company might improve both.

It is surprising that all of these authors, after arguing for a negative relationship between quality and productivity, concluded by allowing for the possibility of a positive relationship given innovation. Furthermore, examples to support the point abound in services, and include both radical or Schumpeterian innovations (1934) and the more common incremental or Kirznerian innovations (1973). If a call center were to adopt a radical innovation such as an advanced customer interface system that enabled customers to quickly and easily gain access to the information they needed without human help, then both productivity and quality might increase. But if the call center employees informally developed and communicated to each other 
a new and useful way to handle a particular type of customer complaint this would constitute an incremental innovation, and again both productivity and quality might increase. In the end, there are many ways managers can increase both service quality and productivity, and the key is an innovative mindset throughout the company.

\section{Managerial implications}

The managerial implications of this study can be organized using the Grönroos and Ojasalo (2004) framework in which service productivity results from internal efficiency, external efficiency, and capacity efficiency.

In regards to internal or cost efficiency, managers should remember that their customers as well as their employees provide inputs into the production process. Managers should encourage their customers to participate, and design systems by which customers can actively get involved. By increasing the number of encounters with customers using contact technology such as social network services, mobile applications and smart devices, service companies can increase customer participation and cost efficiency.

In regard to external efficiency or perceived customer quality, managers must understand that customers are also informants who can help them create value for both themselves and the company. Customer satisfaction results from the customer's experience of using the service (Ponsignon, et al., 2018), and systems that enable customers to participate in the process of designing and producing services can increase customer satisfaction. Thus, service companies should design production processes to maximize customer experiences (Kohli and Jaworski, 1990; Verhoef et al., 2009). Such innovative processes can help companies increase their 
understanding of customers (Mehra, 2018), stimulate customers to participate and form loyalty (Petzer and van Tonder, 2019), and maintain customer satisfaction (Verhoef et al., 2010).

Finally, managers must search for ways to use technology to increase capacity efficiency or utilization. By smoothing demand between high and low demand times, managers can increase both service quality and productivity. Technology, including the customer contact technologies mentioned above, can often be used to shift production away from peak demand times. For example, restaurant might adopt a system by which customers can place lunch orders electronically. This might be followed by a series of incremental innovations as both employees and customers learn to use the system effectively, and the result might be improvements in both internal efficiency and customer perceived quality through reduced waiting time. In summary, there are a variety of ways in which both companies and customers can increase their outcomes including higher levels of service quality, productivity and customer satisfaction.

\section{Conclusion}

The services sector of our economy has an increasingly large impact on our economy in general (World Bank, 2018; Worstall, 2016; Yee et al., 2011), and the drivers of performance for service businesses are service quality and productivity (Calabrese, 2012). However, studies on the relationship between service quality and productivity and the impact of this relationship on customer satisfaction have been inconclusive. This study contributes to service research by identifying innovation as the key to simultaneously increasing service quality and productivity. Our findings provide support for a model in which innovation is an antecedent to both service quality and productivity, and customer satisfaction is generated through the positive interaction 
between the two. Furthermore, we found these relationships using a sample of pure service firms, even though Anderson et al. (1997) had predicted that the tradeoff between quality and productivity was most likely to be found within such firms.

Of course, there are limitations to this study, and these offer opportunities for future research. First, our sample size is relatively small. Also, we could not show differences between industries because we only collected data in the pure services sector. Incorporating a variety of service businesses in the future studies, including those that offer a goods-services package to their customers, may show differences between them and offer other insightful results.

Another potentially fruitful opportunity for future research relates to our measure of our most important independent variable - service innovation - which we measured as R\&D expenditures divided by total assets. This is a reasonable proxy because companies that spend more on $R \& D$ are likely to be more innovation oriented, but it is admittedly a rather crude measure. Ordanini and Parasuraman (2011), for example, distinguished between innovations resulting from customer collaboration, business partner collaboration, and employee collaboration, and suggest that each of these may have differing effects on both the volume of incremental innovations and the likelihood of radical innovations. Innovations resulting from different kinds of collaboration may have different effects on both service quality and productivity, and incremental and radical innovations may also have differing effects. Skålén et al. (2015) provided a different perspective, classifying service innovations as adaptive, resourcebased, practice-based or combinative depending on whether the innovation results from new resources or new practices, and each of these four types of innovations may have different effects on both service quality and productivity. Further investigation of the effects of different kinds of innovation is clearly needed. 
A final avenue for future research relates to our ultimate dependent variable, which is not customer satisfaction but rather firm performance. Practicing managers are interested in customer satisfaction especially because it is thought to be related to firm performance, which can be measured in different ways. Ordanini and Parasuraman (2011), for example, distinguish between revenue growth and earnings growth as performance measures, and firm performance can be conceptualized in a variety of other ways as well (Richard et al, 2009). Further investigation of the effects of service innovation, quality and productivity on the various perspectives on firm performance may be a very fruitful avenue for future research. 


\section{References}

Adeinat, I. and Kassim, N. (2019), "Extending the service profit chain: the mediating effect of employee productivity,” International Journal of Quality and Reliability Management, Vol. 36 No. 5, pp. 797-814.

Agarwal, S., Krishna Erramilli, M., and Dev, C. S. (2003), "Market orientation and performance in service firms: role of innovation,” Journal of Services Marketing, Vol. 17 No. 1, pp. 68-82.

Anderson, E.W., and Sullivan, M.W. (1993), "The antecedents and consequences of customer satisfaction for firms,” Marketing Science, Vol. 12 No. 2, pp. 125-143.

Anderson, E.W., Fornell, C., and Rust, R.T. (1997), "Customer satisfaction, productivity, and profitability: Difference between goods and services,” Marketing Science, Vol. 16 No. 2, pp. 129-145.

Badescu, M., and Garces-Ayerbe, C. (2009), “The impact of information technologies on firm productivity: Empirical evidence from Spain,” Technovation, Vol. 29 No. 2, pp. 122-129.

Bentler, P. M., and Bonett, D. G. (1980) "Significance tests and goodness of fit in the analysis of covariance structures." Psychological Bulletin, Vol.88 No. 3, pp. 588-606.

Berry, L.L., Venkatesh, S., Parish, J.T., Cadwallader, S., and Dotzel, T. (2006), “Creating new markets through service innovation,” MIT Sloan Management, Vol. 47 No. 2, pp. 56-63.

Calabrese, A. (2012), "Service productivity and service quality: A necessary trade-off?," International Journal of Production Economics, Vol. 135 No. 2, pp. 800-812.

Cheng, C.C., Chen, F., and Tsou, H.Tl. (2012), "Market-creating service innovation: verification and its associations with new service development and customer involvement," Journal of Service Marketing, Vol. 26 No. 6, pp. 444-457.

Cheng, C.C., and Krumwiede, D. (2012), "The role of service innovation in the market orientation—new service performance linkage,” Technovation, Vol. 32 No. 7-8, pp. 487497.

Cheruiyot, T. K., and Maru, L.C. (2013), "Service quality and relative performance of public universities in East Africa,” The TQM Journal, Vol. 25 No. 5, pp. 533-546.

Choi, K., Lee, D. \& Olson, D.L. (2015), "Service quality and productivity in the U.S. airline industry: a service quality-adjusted DEA model”, Service Business, 9(1), 137-160.

Churchill, G.A., and Surprenant, C. (1982), “An investigation into the determinants of customer satisfaction,” Journal of Marketing Research, Vol. 19 No. 4, pp. 491-504.

Coombs, R., and Miles, I. (2000), "Innovation, measurement, and services: The new problematic," In J. and. Metcalfe, Innovation Systems in the Service Economy (pp. 85103). Springer. 
Fornell, C., and Wernerfelt, B. (1987), "Defensive marketing strategy by customer complaint management,” Journal of Marketing Research, Vol. 24 No. 4, pp. 337-346.

Fornell, C., and Wernerfelt, B. (1988), “Model for customer complaint management,” Marketing Science, (Summer), pp. 271-286.

Fornell, C., Johnson, M.D., Anderson, E.W., Cha, J., and Everitt, B. (1996), “The American Customer Satisfaction Index: Nature, Purpose, and Findings.” Journal of Marketing, Vol. 60 No. 4, pp. 7-18.

Fornell, C., Morgeson, F.V., and Hult, T.M. (2016), "Stock returns on customer satisfaction do beat the market: Gauging the effect of marketing intangible,” Journal of Marketing, Vol. 80 No. 3, pp. 92-107.

Grenci, R. T., and Watts, C. A. (2007), "Maximizing customer value via mass customized econsumer services,” Business Horizons, Vol. 50 No. 2, pp. 123-132.

Grönroos, C., and Ojasalo, K. (2004), "Service productivity: Towards a conceptualization of the transformation of inputs into economic results in services," Journal of Business Research, Vol. 57 No. 4, pp. 414-423.

Gummesson, E. (2008), “Quality, service-dominant logic and many-to-many marketing,” The TQM Journal, Vol. 20 No. 20, pp. 143-153.

Hair Jr, J. F., Sarstedt, M., Hopkins, L., and Kuppelwieser, V. G. (2014). Partial least squares structural equation modeling (PLS-SEM). European Business Review, Vol. 26 No. 2, pp. 106-121.

Hallowell, R. (1996), "The relationships of customer satisfaction, customer loyalty, and profitability: An empirical study,” International Journal of Service Industry Management, Vol. 7 No. 4, pp. 27-42.

Hennig-Thruau, T., and Klee, A. (1997), "The impact of customer satisfaction and relationship quality on customer retention: A critical reassessment and model development," Psychology and Marketing, Vol. 14 No. 8, pp. 737-764.

Hirschman, A. (1970), Exit, Voice, and Loyalty - Responses to declines in firms, organizations, and states. Cambridge, MA: Harvard University Press.

Holbrook, M.B., and Hirschman, E.C. (1982), "The experiential aspects of consumption: Consumer fantasies, feelings, and fun,” Journal of Consumer Research, Vol. 9 No. 3, pp. 132-140.

Hollebeek, L.D., and Andreassen, T.W. (2018), "The S-D logic-informed "hamburger" model of service innovation and its implications for engagement and value," Journal of Services Marketing, Vol. 32 No. 1, pp. 1-7.

Huff, L., Fornell, C., \& Anderson, E. (1996), “Quality and Productivity: Contradictory and Complementary”, Quality Management Journal, 4(1), 22-39. 
Hurley, R.F., and Hult, G.T. (1998), "Innovation, market orientation, and organizational learning: An integration and empirical examination,” Journal of Marketing, Vol. 62 No. 3, pp. 42-54.

Kasiri, L.A., Cheng, K.T.G., Sambasivan, M., and Sidin, S.M. (2017), “Integrating of standardization and customization: Impact on service quality, customer satisfaction, and loyalty,” Journal of Retailing and Consumer Service, Vol. 35, pp. 91-97.

Kibbeling, M., van der Bij, H., and van Weele, A. (2013), "Market orientation and innovativeness in supply chains: Supplier's impact on customer satisfaction," Journal of Production Innovation Managment, Vol. 30 No. 3, pp. 500-515.

Kirzner, I. (1973), Competition and Entrepreneurship. Chicago: University of Chicago Press. Kohli, A.K., and Jaworski, B.J. (1990), "Market Orientation: The construct, research propositions, and managerial implications,” Journal of Marketing, Vol. 54 No. 2, pp. 118.

Lee, J., Patterson, P.G, and Ngo, L.V. (2017), "In pursuit of service productivity and customer satisfaction: the role of resources,” European Journal of Marketing, Vol. 51 No. 11/12, pp. 1836-1855.

Lohmöller JB. (1989), Predictive vs. Structural Modeling: PLS vs. ML. In: Latent Variable Path Modeling with Partial Least Squares. Heidelberg, DE: Springer.

Lovelock, C.H., and Young, R.F. (1979), “Look to consumers to increase productivity,” Harvard Business Review, Vol. 57 No. 3, pp. 168-178.

Mansury, M.A., and Love, J.H. (2008), "Innovation, productivity and growth in US business services: A firm-level analysis,” Technovation, Vol. 28 No. 1-2, pp. 52-62.

Mehra, S. (2018), “Using asset-based criterion to implement quality management philosophy in service operations to enhance business performance,” International Journal of Quality and Reliability Management, Vol. 35 No. 10, pp. 2195-2211.

Oliver, R. (1980), “A cognitive model of the antecedents and consequences of satisfaction decisions,” Journal of Marketing Research, Vol. 17 No. 4, pp. 460-469.

Ordanini, A., and Parasuraman, A. (2011), "Service innovation viewed through a servicedominant logic lens: A conceptual framework and empirical analysis," Journal of Services Research, Vol. 14 No. 1, pp. 3-23.

Padgett, R.C., and Galan, J.I. (2010), "The effect of RandD intensity on corporate social responsibility," Journal of Business Ethics, Vol. 93 No. 3, pp. 407-418.

Parasuraman, A. (2010), "Service productivity, quality and innovation: Implications for service-design practice and research", International Journal of Quality and Service Sciences, 2(3), 277-286.

Parasuraman, A., Zeithaml, V.A., and Berry, L.L. (1985), “A conceptual model of service quality and its implications for future research,” Journal of Marketing, Vol. 49 No. 4, pp. 41-50. 
Parasuraman, A., Zeithaml, V.A., and Berry, L.L. (1988), "Servqual: A multiple-item scale for measuring consumer perception of service quality,” Journal of Retailing, Vol. 64 No. 1, pp. 12-40.

Parasuraman, A., Zeithaml, V. A., and Berry, L. L. (1994), "Reassessment of expectations as a comparison standard in measuring service quality: implications for further research,” Journal of Marketing, Vol. 58 No. 1, pp. 111-124.

Peterson, R.A., and Jeong, J. (2010), "Exploring the impact of advertising and RandD expenditures on corporate brand value and firm-level financial performance," Journal of the Academy of Marketing Science, Vol. 38 No. 6, pp. 677-690.

Petzer, D.J. and van Tonder, E. (2019), "Loyalty intentions and selected relationship quality constructs: The mediating effect of customer engagement," International Journal of Quality and Reliability Management, Vol. 36 No. 4, pp. 601-619.

Ponsignon, F., Smart, A. and Phillips, L. (2018), “A customer journey perspective on service delivery system design: Insights from healthcare,” International Journal of Quality and Reliability Management, Vol. 35 No. 10, pp. 2328-2347.

Rahmi, R., and Kozak, M. (2017), "Impact of customer relationship management on customer satisfaction,” Journal of Travel and Tourism Marketing, Vol. 34 No. 1, pp. 40-51.

Richard, P.J, Devinney, T.M, Yip, G.S., and Johnson, G. (2009), "Measuring organizational performance: Towards methodological best practices.” Journal of Management, Vol. 35, pp. 718-804.

Rust, R.T., and Huang, M.H. (2012), “Optimizing service productivity,” Journal of Marketing, Vol. 76 No. 2, pp. 47-66.

Schumpeter, J. (1934), Theories of economic development. Cambridge, MA: Transaction Publisher.

Skålén, P., Gummerus, J., von Koskull, C., and Magnusson, P.R. (2015), “Exploring value propositions and service innovation: A service-dominant logic study," Journal of the Academy of Marketing Sciences, Vol. 43, pp. 137-158.

Szymanski, D.M., and Henard, D.H. (2001), "Customer satisfaction: A meta-analysis of the empirical evidence,” Journal of the Academy of Marketing Science, Vol. 29 No. 1, pp. 16-35.

Taylor, S.A., and Baker, T.L. (1994), "An assessment of the relationship between service quality and customer satisfaction in the formation of consumers' purchase intentions," Journal of Retailing, Vol. 70 No. 2, pp. 163-178.

Vargo, S.L., and Lusch, R.F. (2004), “Evolving to a new dominant logic for marketing,” Journal of Marketing, Vol. 68 No. 1, pp. 1-17.

Vargo, S.L., and Lusch, R.F. (2008a), "Service-Dominant Logic: Continuing the evolution," Journal of the Academy of Marketing Science, Vol. 36 No. 1, pp. 1-10. 
Vargo, S.L., and Lusch, R.F. (2008b), "Why "service"?,” Journal of the Academic of Marketing Science, Vol. 36 No. 1, pp. 25-38.

Vargo, S. L., Maglio, P. P., and Akaka, M. A. (2008), "On value and value co-creation: A service systems and service logic perspective,” European Management Journal, Vol. 26 No. 3, pp. 145-152.

Verhoef, P. C., Lemon, K. N., Parasuraman, A., Roggeveen, A., Tsiros, M., and Schlesinger, L. A. (2009), "Customer experience creation: Determinants, dynamics and management strategies,” Journal of Retailing, Vol. 85 No. 1, pp. 31-41.

Verhoef, P.C., Reinartz, W.J., and Krafft, M. (2010), “Customer engagement as a new perspective in customer management," Journal of Service Research, Vol. 13 No. 3, pp. 247-252.

Witell, L., Snyder, H., Gustafsson, A., Fombelle, P., and Kristensson, P. (2016), “Defining service innovation: A review and synthesis,” Journal of Business Research, Vol. 69, pp. 2863-2872.

World Bank (2018), The World Bank. Retrieved from Services, etc., value added (\% of GDP): https://data.worldbank.org/indicator/NV.SRV.TETC.ZS/

Worstall, T. (2016), Forbes. Retrieved from Services, The Only Important Part Of The US Economy, Growing Nicely - PMI to 57.1\%: https://www.forbes.com/sites/timworstall/2016/10/05/services-the-only-important-partof-the-us-economy-growing-nicely-pmi-to-57-1/\#57a2784e1d1c

Yee, R., Yeung, A., and Cheng, T.C. (2008), "The impact of employee satisfaction on quality and profitability in high-contact service industries,” Journal of Operation Management, Vol. 26 No. 5, pp. 651-668.

Yee, R. Yeung, A., and Cheng, T.C.E. (2011), "The service-profit chain: An empirical analysis in high-contact service industries," International Journal of Production and Economics, Vol. 130 No. 2, pp. 236-245.

Yen, H.R., Wang, W., Wei., C.P., Hsu, S.H.Y., and Chiu, H.C. (2012), "Service innovation readiness: Dimensions and performance outcome,” Decision Support Systems, Vol. 53 No. 4, pp. 813-824.

Yi, Y., Nataraajan, R., and Gong, T. (2011), "Customer participation and citizenship behavioral influences on employee performance, satisfaction, commitment, and turnover intention," Journal of Business Research, Vol. 64 No. 1, pp. 87-95.

Yoon, M.H., and Suh, J. (2003), "Organizational citizenship behaviors and service quality as the external effectiveness of contact employees,” Journal of Business Research, Vol. 56 No. 8, pp. 597-611.

Zeithaml, V.A., Berry, L.L., and Parasuraman, A. (1996), "The behavioral consequences of service quality,” Journal of Marketing, Vol. 56 No. 3, pp. 31-46. 